MATH DIDACTIC: JURNAL PENDIDIKAN MATEMATIKA

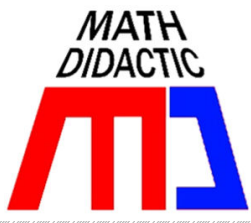

\author{
PENGEMBANGAN BAHAN AJAR RELASI REKURENSI BERBASIS BLENDED \\ LEARNING DAN BERWAWASAN LINGKUNGAN LAHAN BASAH UNTUK \\ MENINGKATKAN KEMAMPUAN BERPIKIR TINGKAT TINGGI MAHASISWA
}

\title{
DEVELOPMENT OF LEARNING MATERIALS IN RECURRENCE RELATIONS BASED ON BLENDED LEARNING AND WET LAND ENVIRONMENT TO INCREASE HIGHER ORDER THINKING SKILL OF STUDENTS
}

\author{
Noor Fajriah, Taufiq Hidayanto, Rizki Amalia \\ Universitas Lambung Mangkurat \\ n.fajriah@ulm.ac.id, taufiq.hidayanto@ulm.ac.id,amaliarizki@ulm.ac.id
}

\begin{abstract}
Abstrak: Perguruan Tinggi diharapkan dapat menyiapkan sumber daya manusia yang berkompeten dan mampu bersaing di dunia kerja khususnya pada revolusi industri 4.0. Salah satu bentuk jawaban dari tantangan revolusi industri 4.0 dalam praktik pembelajaran di Perguruan tinggi adalah pemanfaatan e-learning. Penelitian ini bertujuan untuk mengembangkan bahan ajar materi relasi rekurensi berbasis blended learning yang valid dan efektif. Bahan ajar dikembangkan menurut prosedur pengembangan bahan ajar 4D (Define, Design, Develop, dan Disseminate). Pengembangan hanya difokuskan pada tahap Define, Design, dan Develop. Pada tahap develop, ahli yang dilibatkan sebagai validator sebanyak dua orang pada sesi penilaian ahli (expert appraisal). Hasil validasi bahan ajar adalah $V a=3,38$ dan berskor lebih dari atau sama dengan 2 pada setiap aspek di masing-masing validator, sehingga bahan ajar dinyatakan valid. Setelah bahan ajar divalidasi, bahan ajar diuji keefektifannya dengan melibatkan 42 mahasiswa sebagai subjek pada sesi Uji Pengembangan (Developmental Testing). Hasil uji keefektifannya yaitu $K a=3,30$ dan berskor lebih dari atau sama dengan 2 pada setiap aspek di masing-masing subjek uji. Oleh karena itu, bahan ajar dinyatakan efektif.
\end{abstract}

Kata Kunci: bahan ajar, blended learning, relasi rekurensi, berpikir tingkat tinggi

Abstract: Higher Education is expected to be able to prepare competent human resources and able to compete in the world of work, especially in the industrial revolution 4.0. One form of answers to the challenges of the industrial revolution 4.0 in the practice of learning in tertiary institutions was the use of e-learning. This study aims to develop learning materials for recurrence relations based on blended learning that were valid and effective. Learning materials were developed according to the procedure of $4 D$ - developing learning materials (Define, Design, Develop, and Disseminate). Development is only focused on the Define, Design and Develop stages. At the develop stage, there were two experts involved as validators in the expert appraisal session. The results of the validation of learning materials were $V a=3.38$ and score more than or equal to 2 in each aspect $d$ of each validator, so the teaching material was declared valid. After the learning materials were validated, the learning materials were tested for their effectiveness by involving 42 students as subjects in the Developmental Testing session. The effectiveness test results were $K a=3.30$ and score more than or equal to 2 in each aspect of each test subject. Therefore, learning materials were declared effective.

Keywords: learning materials, blended learning, recurrence relations, higher order thinking

Cara Sitasi: Fajriah, N., Hidayanto, T., \& Amalia, R. (2020). Pengembangan bahan ajar relasi rekurensi berbasis blended learning dan berwawasan lingkungan lahan basah untuk meningkatkan kemampuan berpikir tingkat tinggi mahasiswa. Math Didactic: Jurnal Pendidikan Matematika, 6(2), 142-155. https://doi.org/10.33654/math.v6i2.929 
Perguruan Tinggi merupakan salah satu institusi yang berperan dalam penentu kesuksesan pembangunan Indonesia karena diharapkan dapat menyiapkan sumber daya manusia yang berkompeten dan mampu bersaing di dunia kerja khususnya pada revolusi industri 4.0. Salah satu bentuk jawaban dari tantangan revolusi industri 4.0 dalam praktik pembelajaran di Perguruan tinggi adalah pemanfaatan e-learning.

E-learning dapat diimplementasikan dalam perkuliahan melalui blended learning. Blended learning adalah pembelajaran yang mengintegrasikan praktik face-to-face dan pembelajaran online (Broke, 2017; Bryan \& Volchenkova, 2016; Sari, 2016). Perkuliahan dengan Blended learning memberikan kesempatan kepada mahasiswa untuk belajar dengan mudah dan lebih terbuka. Karakteristik materi yang dapat digunakan, setidaknya dapat dipelajari secara mandiri oleh mahasiswa. Salah satu materi yang dapat diajarkan melalui blended learning adalah materi relasi rekurensi.

Relasi rekurensi didasarkan pada materi rekursi. Rekursi adalah suatu proses pengulangan dengan cara memanggil dirinya sendiri, sehingga dengan ciri tersebut maka rekursi merupakan salah satu konsep yang penting untuk dikuasai oleh mahasiswa. Rekursi bermanfaat di bidang komputer, dalam pemrograman prosedural, seperti bahasa pemrograman $\mathrm{C}$, atau metode pada pemrograman berorientasi objek seperti $\mathrm{C}++$ atau Java.

Berdasarkan hasil perkuliahan tahun sebelumnya, rekursi adalah materi yang sulit dimengerti oleh mahasiswa. Hal ini terlihat dari nilai rata-rata mahasiswa pada materi rekursi hanya mencapai 33,67. Nilai tersebut cukup memprihatinkan karena masih di bawah batas kelulusan. Ada beberapa penyebab kesulitan mahasiswa, antara lain: rekursi merupakan materi yang baru, bahan ajar yang digunakan berbahasa Inggris sehingga perlu waktu dan penjelasan dari dosen terlebih dahulu untuk memahaminya. Selanjutnya, soal yang dikerjakan siswa memerlukan penalaran untuk memecahkannya. Sehingga, perlu adanya solusi untuk mengatasi berbagai masalah tersebut.

Mayoritas mahasiswa Program Studi Pendidikan Matematika Universitas Lambung Mangkurat berasal dari Provinsi Kalimantan Selatan. Kearifan lokal (local wisdom) yang ada di Kalimantan Selatan berkenaan dengan lingkungan lahan basah karena sebagian besar wilayah Kalimantan Selatan berupa lahan rawa. Di sisi lain, konsep matematika yang dipelajari mahasiswa dapat dikombinasikan dengan kearifan lokal di sekitar lingkungannya (Maryati \& Prahmana, 2018). Lebih lanjut, Rohaeti (2011) berpendapat bahwa matematika yang diajarkan di sekolah diharapkan tidak terpisahkan dari konsepkonsep yang ada dalam keseharian siswa. Senada dengan pernyataan Gazali (2016), kearifan lokal lingkungan lahan basah yang diintegrasikan dalam pembelajaran matematika kontekstual diharapkan mampu menjadi pembelajaran yang bermakna karena terkait dengan komunitas dimana mahasiswa berasal. Lebih jauh, dengan pembelajaran berwawasan lingkungan lahan basah, mahasiswa dapat menjadi agen perubahan dalam menjawab permasalahan-permasalahan di daerahnya.

Salah satu solusi yang diusahakan untuk memaksimalkan kemampuan berpikir mahasiswa adalah mengembangkan bahan ajar relasi rekurensi yang kontekstual. Materi yang dihubungkan dengan konteks sehari-hari akan meningkatkan kemampuan pemecahan masalah (Surya \& Putri, 2017). Konteks yang 
dikembangkan dalam bahan ajar adalah lingkungan lahan basah. Harapannya, pembelajaran yang mengimplementasikan bahan ajar berwawasan lingkungan lahan basah dapat memaksimalkan kemampuan berpikir tingkat tinggi mahasiswa.

Anderson \& Krathwohl telah memperbaharui taksonomi tujuan pendidikan yang sebelumnya dikemukakan oleh Bloom menjadi lebih berbentuk kata kerja, yaitu: (a) remembering, (b) understanding, (c) applying, (d) analyzing, (e) evaluating, dan (f) creating. Oleh karena itu, tujuan pendidikannya lebih bernuansa kegiatan kognitif, bukan produk dari kegiatan kognitif. Dalam hal ini, HOTS dikategorikan dalam kegiatan analyzing (menganalisis), evaluating (mengevaluasi), dan creating (mencipta) (As'ari, Ali, Basri, Kurniati, \& Maharani, 2019). Bahan ajar yang dikembangkan memberikan kesempatan kepada mahasiswa untuk menganalisis, mengevaluasi, dan mencipta agar mereka terfasilitasi dalam meningkatkan kemampuan berpikir tingkat tingginya. Di sisi lain, kemampuan berpikir tingkat tinggi mempunyai hubungan dengan prestasi belajar (Tanujaya, Mumu, \& Margono, 2017). Artinya jika memaksimalkan kemampuan mahasiswa dalam pembelajaran akan memaksimalkan nilai kelulusannya.

Penelitian pengembangan bahan ajar untuk meningkatkan kemampuan berpikir tingkat tinggi telah dilakukan oleh Anisah \& Lastuti (2018); Mursalin et al. (2018); Musfiqi \& Jailani (2014); Mutrofin, Nur, \& Yuanita (2016); Nur (2017). Namun, belum ada pengembangan bahan ajar berbasis blended learning yang berwawasan lingkungan lahan basah dan untuk meningkatkan kemampuan berpikir tingkat tinggi. Berdasarkan permasalahan dan kajian yang telah disampaikan, tujuan penelitian ini adalah mengembangkan bahan ajar pada materi relasi rekurensi berbasis blended learning dan berwawasan lingkungan lahan basah untuk meningkatkan kemampuan berpikir tingkat tinggi mahasiswa.

\section{Metode Penelitian}

Bahan ajar yang dikembangkan pada materi relasi rekurensi pada mata kuliah matematika diskrit. Pengembangan bahan ajar ini didasarkan pada model 4-D yang dikemukakan oleh Thiagarajan, Semmel, \& Semmel (1974) meliputi pembatasan (define), perancangan (design), pengembangan (develop), dan penyebarluasan (disseminate). Peneliti memodifikasi model pengembangan tersebut yaitu dengan penyederhanaan model menjadi tiga tahapan: pembatasan (define), perancangan (design), dan pengembangan (develop). Modifikasi selanjutnya adalah tidak semua tahapan define-design-develop pada model 4-D digunakan dengan alasan disesuaikan dengan kebutuhan pengembangan bahan ajar.

Uji coba produk dilakukan dengan melakukan uji kevalidan yaitu uji perseorangan dan uji keefektifan yaitu uji kelompok kecil. Subjek uji coba adalah mahasiswa prodi Pendidikan matematika yang sedang menempuh mata kuliah matematika diskrit sebanyak 42 orang dengan perbedaan jenis kelamin, kemampuan, maupun latar belakang sosial-ekonomi.

Teknik analisis data dalam penelitian ini adalah teknik analisis data hasil uji kevalidan, teknik analisis data hasil uji keefektifan produk, dan teknis analisis data hasil tanggapan mahasiswa. Teknik analisis data hasil uji kevalidan berupa teknik analisis deskriptif karena data yang diperoleh dalam penelitian ini berupa hasil jawaban kuesioner 
dari para responden dan penarikan kesimpulannya diuraikan dengan mengacu pada kriteria pencapaian nilai tertentu. Data kuantitatif hasil validasi dianalisis dengan menggunakan teknik analisis rata-rata berdasarkan langkah-langkah berikut ini.

Menentukan rata-rata dari semua validator untuk setiap indikator $\left(I_{i}\right)$

$$
I_{i}=\frac{\sum_{j=1}^{n} V_{j i}}{n}
$$

dengan $V_{j i}$ adalah nilai dari validator ke- $j$ terhadap indikator ke- $i$ dan $n$ adalah banyaknya validator.

Menentukan skor kevalidan $\left(\mathrm{V}_{a}\right)$

$$
V_{a}=\frac{\sum_{i=1}^{m} I_{i}}{m}
$$

dengan $\quad I_{i}$ adalah rata-rata nilai indikator ke- $i$ dan $m$ adalah banyaknya indikator.

Bahan ajar yang dikembangkan dikatakan valid jika hasil uji validasi terhadap bahan ajar mencapai skor dengan minimal berkriteria valid. Kriteria penilaian untuk menguji kevalidan bahan ajar adalah sebagai berikut:

$1 \leq V_{a}<2 \quad$ : Bahan ajar tidak valid

$2 \leq V_{a}<3$ : Bahan ajar valid namun perlu ada perbaikan besar

$3 \leq V_{a}<4$ : Bahan ajar valid namun perlu ada perbaikan kecil

$V_{a}=4 \quad$ : Bahan ajar valid dan tidak perlu ada perbaikan

$V_{a}=$ Skor kevalidan

(dimodifikasi dari Hobri, 2010)

Proses validasi tidak diulang (sudah valid) apabila skor kevalidan minimal 2 dan tidak ada skor 1 di beberapa kriteria aspek penilaian

Teknik analisis data hasil uji keefektifan berupa teknik analisis deskriptif karena data yang diperoleh dalam penelitian ini berupa hasil jawaban kuesioner dari para responden dan penarikan kesimpulannya diuraikan dengan mengacu pada kriteria pencapaian nilai tertentu. Data kuantitatif hasil uji keefektifan dianalisis dengan menggunakan teknik analisis rata-rata berdasarkan langkahlangkah berikut:

Menentukan rata-rata dari semua subjek untuk setiap indikator $\left(I_{i}\right)$

$$
I_{i}=\frac{\sum_{j=1}^{n} V_{j i}}{n}
$$

dengan $V_{j i}$ adalah nilai dari subjek ke-j terhadap indikator ke- $i$ dan $n$ adalah banyaknya subjek.

Menentukan skor keefektifan $\left(\mathrm{K}_{a}\right)$

$$
K_{a}=\frac{\sum_{i=1}^{m} I_{i}}{m}
$$

dengan $I_{i}$ adalah rata-rata nilai indikator ke- $i$ dan $m$ adalah banyaknya indikator.

Bahan ajar yang dikembangkan dikatakan efektif jika hasil uji keefektifan terhadap bahan ajar mencapai skor dengan minimal berkriteria efektif. Kriteria penilaian untuk menguji keefektifan bahan ajar adalah sebagai berikut:

$1 \leq K_{a}<2$ :Bahan ajar tidak efektif

$2 \leq K_{a}<3$ :Bahan ajar efektif namun perlu ada perbaikan besar

$3 \leq K_{a}<4$ :Bahan ajar efektif namun perlu ada perbaikan kecil

$K_{a}=4 \quad$ :Bahan ajar efektif dan tidak perlu ada perbaikan

$K_{a}=$ Skor Keefektifan.

(dimodifikasi dari Hobri, 2010)

Teknik analisis hasil tanggapan subjek berupa teknik analisis deskriptif naratif karena hasil tanggapan yang diberikan oleh subjek terhadap sajian bahan ajar yang dikembangkan berupa pernyataan-pernyataan justifikasi terkait bahan ajar. Tanggapan subjek 
dikumpulkan dan disimpulkannya dalam beberapa poin hasil tanggapan. Kesimpulan yang telah diperoleh digunakan sebagai bahan pertimbangan untuk merevisi produk yang dikembangkan.

\section{Hasil Penelitian dan Pembahasan}

\section{Hasil}

Hasil penelitian ini dibahas tahap define, design, dan develop produk bahan ajar yang dikembangkan. Adapun masing-masing tahapan diuraikan sebagai berikut.

\section{Tahap Define}

Tahap define meliputi lima kegiatan yang dilakukan oleh peneliti. Lima tahapan tersebut meliputi Front-End Analysis (Analisis Akhir Terdepan), Learner Analysis (Analisis Pembelajar), Task Analysis (Analisis Tugas), Concept Analysis (Analisis Konsep), dan Specifying Instructional Objectives (Pemfokusan Tujuan Pembelajaran).

\section{Front-End Analysis (Analisis Akhir Terdepan)}

Pada analisis akhir-terdepan ini, peneliti menganalisis permasalahanpermasalahan yang terjadi pada perkuliahan matematika diskrit. Perkuliahan yang telah dilaksanakan beberapa tahun terakhir cenderung disampaikan secara klasikal dan menggunakan bahan ajar yang bersumber dari buku asing. Meskipun disajikan lengkap, namun kebanyakan mahasiswa cenderung memerlukan waktu yang lama untuk memahaminya. Sehingga perlu adanya pengembangan bahan ajar yang disajikan lebih ringkas. Selain itu, tantangan ke depan adalah mahasiswa dituntut untuk menguasai literasi digital. Karena perkuliahan selama ini cenderung klasikal, perlu adanya perkuliahan secara blended learning yang memungkinkan mahasiswa untuk lebih melek teknologi.

\section{Learner Analysis (Analisis Pembelajar)}

Mahasiswa pendidikan matematika bervariasi dalam hal jenis kelamin, kemampuan matematis, sosial, maupun kemampuan ekonominya. Namun, dalam penelitian ini yang diperhatikan adalah varietas kemampuan matematis dan kemampuan ekonomi mahasiswa. Dengan kemampuan matematis yang variatif dan kemampuan ekonomis mahasiswa maka bahan ajar yang dikembangkan ringkas dan terintegrasi dengan e-learning Universitas Lambung Mangkurat (ULM) yang dapat diakses oleh seluruh mahasiswa.

\section{Task Analysis (Analisis Tugas)}

Pada pelaksanaan perkuliahan sebelum-sebelumnya, tugas-tugas yang diberikan seringnya langsung diambil dari latihan-latihan soal yang ada di buku ajar. Selain itu, karena buku ajarnya dari terbitan asing, terapan-terapan konsep dikaitkan dengan permasalahan dari lingkungan buku diterbitkan. Untuk itu, peneliti mempertimbangkan permasalahanpermasalahan yang dikaitkan dengan lingkungan mahasiswa, yaitu lingkungan lahan basah.

\section{Concept Analysis (Analisis Konsep)}

Materi yang dikembangkan bahan ajarnya adalah relasi rekurensi. Materi relasi rekurensi ini merupakan lanjutan dari konsep fungsi rekursi. Materi relasi rekurensi lebih banyak pada konsep-konsep dan masalahmasalah yang bersifat prosedural. Oleh karena itu, bahan ajar yang dikembangkan lebih banyak memberikan latihan-latihan. 


\section{Specifying Instructional Objectives (Pemfokusan Tujuan Pembelajaran)}

Bahan ajar yang dikembangkan pada materi relasi rekurensi dengan spesifikasi sub materinya adalah Aplikasi Relasi Rekurensi dan Menyelesaikan Masalah yang Berkenaan dengan Relasi Rekurensi Linear Homogen dengan Koefisien Konstan. Indikatornya meliputi Memahami relasi rekurensi yang dikaitkan dengan konsep fungsi rekursif, Menjelaskan prosedur penyelesaian masalah relasi rekurensi homogen dengan koefisien konstan, Menyelesaikan masalah relasi rekurensi homogen dengan koefisien konstan, dan Menyusun dan menyelesaikan masalah relasi rekurensi homogen dengan koefisien konstan.

\section{Tahan Design}

Tahapan design pada penelitian ini terdiri atas Constructing Criterion-Referenced Test (Pengonstruksian Test Berbasis-Kriteria), Media Selection (Pemilihan Media), Format Selection (Pemilihan Format), dan Initial Design (Rancangan Awal).

\section{Constructing Criterion-Referenced Test (Pengonstruksian Test Berbasis-Kriteria)}

Wujud dari tes ini adalah instrumen penilaian yang berisi ringkasan aspek yang dinilai dari produk yang dikembangkan. Tes yang dikembangkan menguji kevalidan dan keefektifan bahan ajar pada materi relasi rekurensi yang diterapkan dalam pembelajaran blended learning dengan e-learning. Tes uji kevalidan dan keefektifan berupa kuesioner. Tes kevalidan ditujukan kepada ahli, sedangkan uji keefektifan ditujukan kepada mahasiswa sebagai subjek uji.

\section{Media Selection (Pemilihan Media)}

Analisis yang telah dilakukan pada tahap pendefinisian menghasilkan suatu kesimpulan tentang produk yang akan dikembangkan, yaitu Bahan ajar cetak yang dapat diterapkan dengan blended learning melalui e-learning.

\section{Format Selection (Pemilihan Format)}

Format bahan ajar yang dikembangkan yaitu modul kuliah matematika diskrit dan terfokus pada materi relasi rekurensi. Bagian awal berisi identitas materi, Capaian Pembelajaran Mata Kuliah (CP-MK), indikator, dan sumber/referensi. Bagian berikutnya yaitu materi. Materi disajikan berdasarkan tata urutan CORE (Connecting, Organizing, Reflecting, dan Extending). Pada fase Connecting, bahan ajar memuat materi relasi rekurensi dan dikaitkan dengan masalah kontekstual dengan kearifan lokal Kalimantan Selatan. Pada fase Organizing, bahan ajar memuat perintah kepada mahasiswa untuk mencari konsep yang berkenaan dengan relasi rekurensi dari berbagai sumber. Pada bagian reflecting, bahan ajar memberikan kesempatan kepada mahasiswa untuk menuliskan konsep menurut pemahamannya sendiri yang didasarkan pada temuannya dari berbagai sumber. Pada bagian extending, bahan ajar menyediakan kesempatan kepada mahasiswa untuk menyelesaikan tugas-tugas terkait dengan relasi rekurensi. Di bagian terakhir, bahan ajar memuat penilaian akhir bab relasi rekurensi.

\section{Initial Design (Rancangan Awal)}

Bahan ajar yang dikembangkan berbentuk modul yang diimplementasikan 
dalam pembelajaran blended learning melalui e-learning. Pembelajaran utama didasarkan pada langkah-langkah pembelajaran CORE.

\section{Tahap Develop}

Tahap develop terdiri atas Expert Appraisal (Penilaian Ahli) dan Developmental Testing (Uji Pengembangan).

\section{Expert Appraisal (Penilaian Ahli)}

Penilaian kepada ahli dilakukan kepada dua orang Dosen Pendidikan Matematika FKIP ULM. Kedua validator diberikan kuesioner yang berisi penilaian berbagai aspek bahan ajar yang dikembangkan dan tanggapan secara kualitatif dituliskan di bagian saran.

Berdasarkan hasil uji validasi bahan ajar oleh validator, rata-rata setiap aspek penilaian memiliki skor $3-4$. Rata-rata dari seluruh penilaian setiap aspek oleh setiap validator menunjukkan nilai 3,38. Berdasarkan kriteria yang telah ditetapkan, bahan ajar yang dikembangkan tergolong valid namun perlu perbaikan kecil. Adapun catatan perbaikan yang diberikan adalah perlunya pemeriksaan kembali redaksi kata maupun di kalimat karena ada beberapa kata salah ketik. Setelah diperbaiki, bahan ajar diujicobakan kepada subjek uji.

\section{Developmental Testing (Uji Pengembangan)}

Uji pengembangan dilakukan untuk menguji keefektifan bahan ajar yang telah dikembangkan kepada mahasiswa sebanyak 42 orang. Mahasiswa mendapatkan pembelajaran dengan menerapkan bahan ajar yang dikembangkan. Perkuliahan dilaksanakan secara blended learning selama 2 pertemuan. Pertemuan pertama tatap muka secara klasikal di kelas, sedangkan pertemuan kedua secara online. Pada pertemuan pertama, mahasiswa mendiskusikan konsep dasar relasi rekurensi bersama dosen, selanjutnya berdiskusi bersama kelompoknya untuk membahas definisi relasi rekurensi. Hasil diskusi seluruh kelompok diunggah di simari.ulm.ac.id melalui fitur "forum". Contoh instruksi tugas dan hasil diskusi pertemuan 1 tersaji pada Gambar 1.

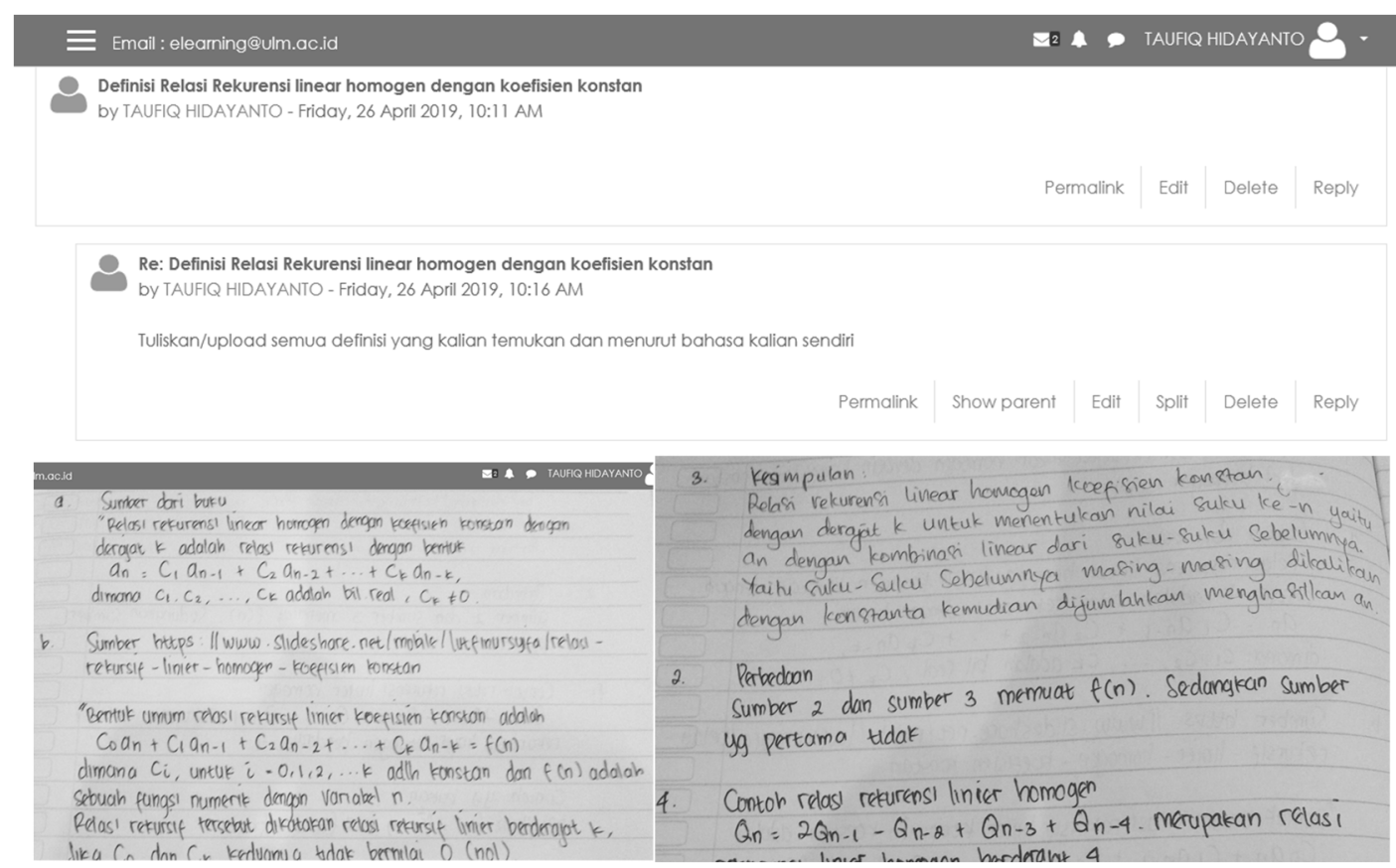

Gambar 1. Instruksi Tugas dan Hasil Diskusi yang Diunggah dalam Simari 
Mahasiswa menuliskan definisi relasi rekurensi berdasarkan sumber yang sudah disampaikan dan menuliskan definisi menurut bahasanya sendiri. Selain itu, mereka menyusun contoh dan non-contoh dari relasi rekurensi untuk memantapkan pemahamannya.

Pada pertemuan kedua, perkuliahan dilaksanakan tidak tatap muka di kelas, namun mahasiswa dapat berdiskusi di tempat sesuai dengan kesepakatan kelompoknya. Mereka mendiskusikan prosedur penyelesaian masalah relasi rekurensi, menyelesaikan contoh masalah, dan mengunggahnya di "forum" simari. Instruksi Tugas dan Hasil unggah mahasiswa tersaji di Gambar 2. Selain tugas secara berkelompok, mahasiswa juga menyelesaikan tugas secara individu. Tugas individu mahasiswa tersaji pada Gambar 3.

Setelah selesai perkuliahan, mahasiswa diberikan kuesioner terkait penggunaan bahan ajar yang telah dikembangkan. Hasil Kuesioner menunjukkan bahwa setiap indikator di setiap subjek tidak ada yang memberikan nilai 1 , setiap aspek memiliki rata-rata lebih dari 2 (bahkan sebagian besar lebih dari 3) dan nilai $\mathrm{Ka}=3,30$, sehingga dapat disimpulkan bahwa bahan ajar yang dikembangkan efektif meski perlu revisi. Aspek yang memiliki rata-rata terkecil adalah "Bahan ajar tidak memuat kata/kalimat yang menimbulkan penafsiran ganda" yaitu 2,90. Untuk itu, pada aspek tersebut perlu ada perlakuan lebih sebagai bahan revisi bahan ajar.

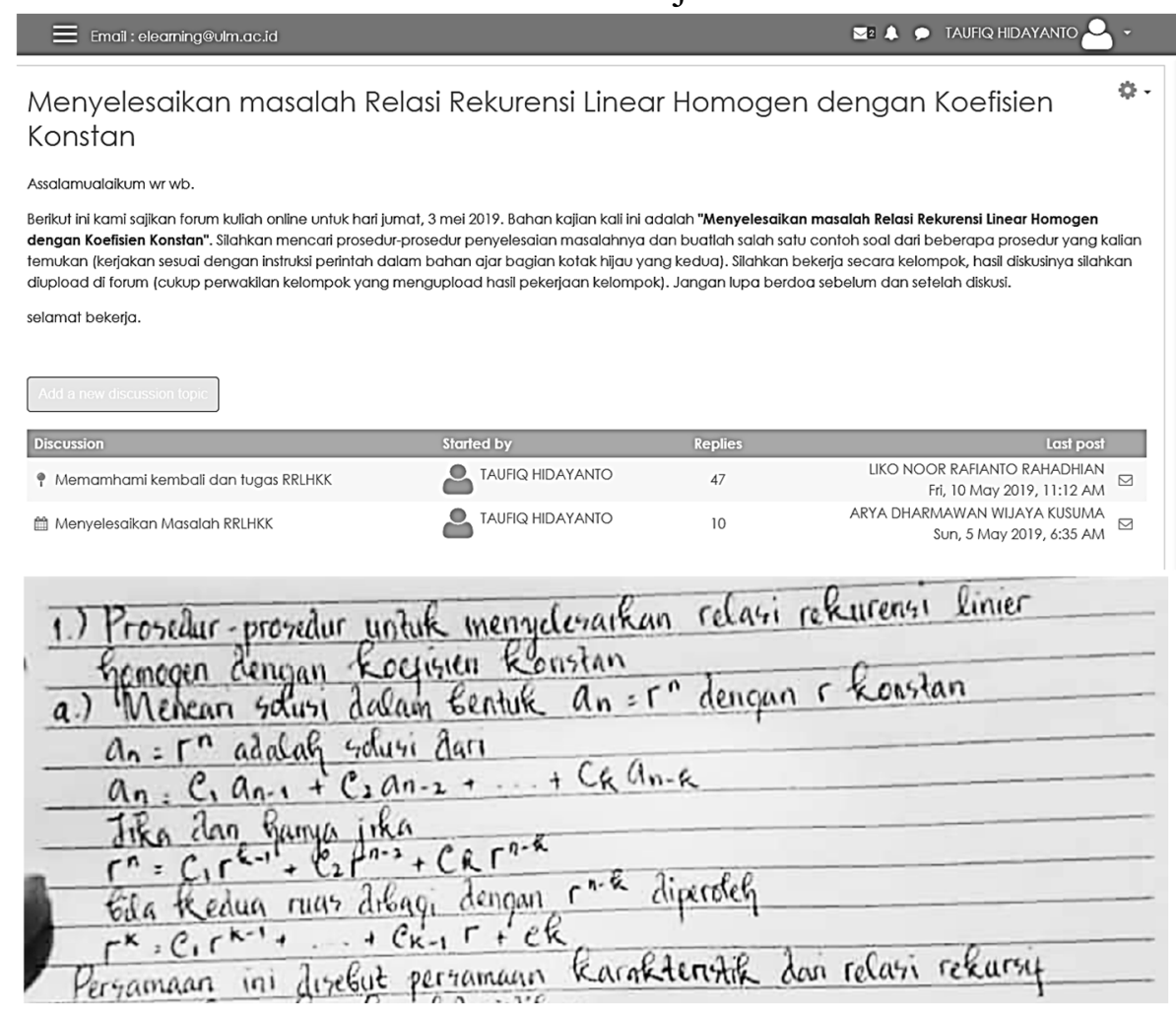

Gambar 2. Instruksi dan Contoh Hasil Unggah Salah Satu Kelompok 


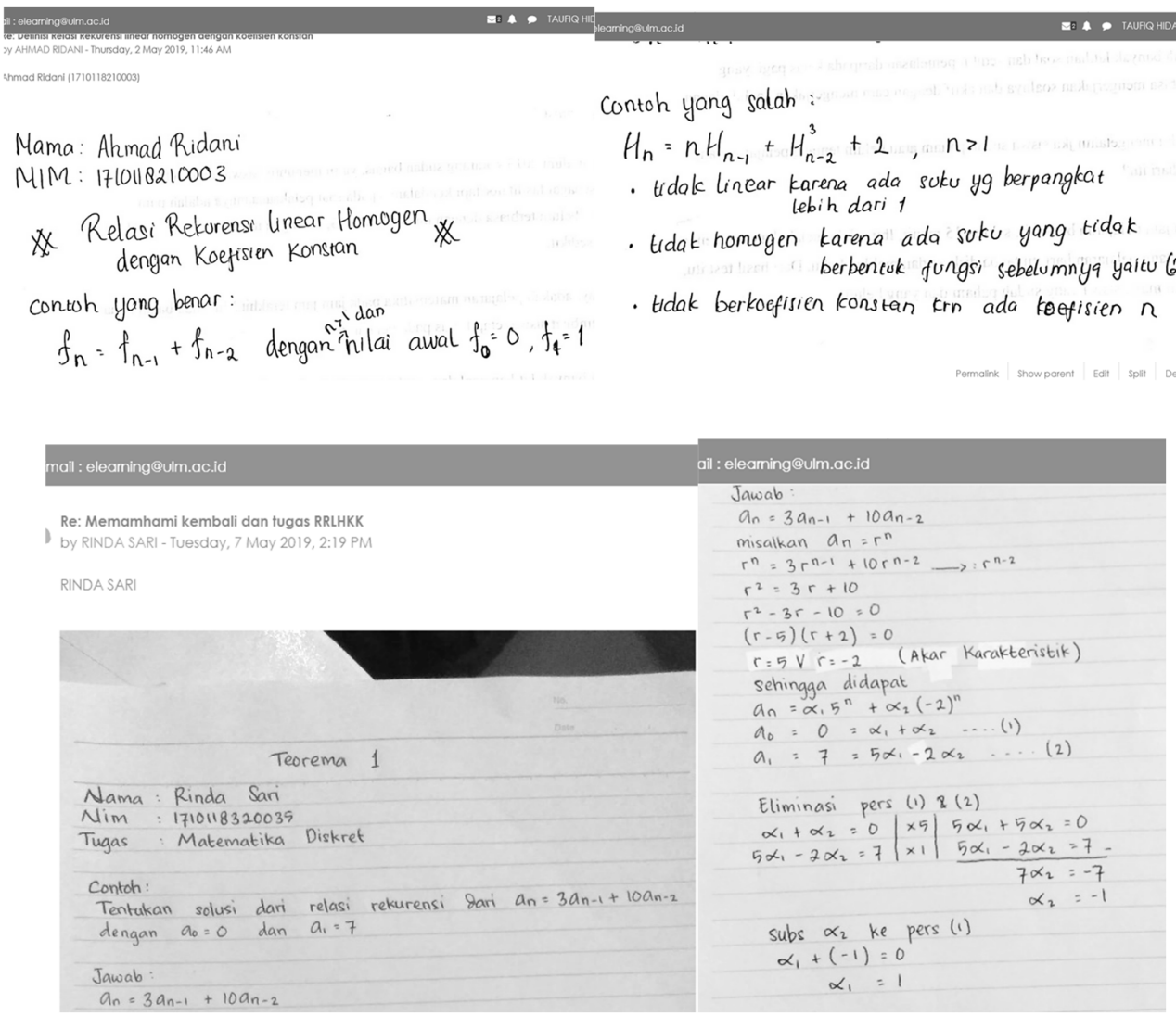

Gambar 3. Tugas Individu Pertemuan 1 dan 2

Tanggapan positif subjek terkait bahan ajar yaitu: (i) membantu dan membuat mahasiswa dapat belajar di mana-mana; (ii) materi yang disajikan membuat mahasiswa aktif mencari tambahan materi dari sumber lain sehingga tidak pasif; (iii) mahasiswa lebih mudah apabila pembelajaran menggunakan model blended; (iv) menuliskan konsep dengan bahasa sendiri membuat mahasiswa menjadi lebih mudah memahami materi

Tanggapan positif ini menunjukkan bahwa beberapa subjek merasa nyaman menggunakan bahan ajar yang telah dikembangkan. Selain adanya tanggapan positif, subjek memberikan beberapa saran untuk perbaikan bahan ajar, yaitu: (i) perlu ada feedback dari tugas yang telah dikumpulkan melalui e-learning; (ii) perlu ada bagian dari bahan ajar yang dipadukan dengan video

\section{Pembahasan}

Bahan ajar yang dikembangkan memperhatikan sintaks model pembelajaran CORE (Connecting, Organizing, Reflecting, dan Extending). Pada fase Connecting, bahan ajar memuat materi relasi rekurensi dan dikaitkan dengan masalah kontekstual dengan kearifan lokal Kalimantan Selatan. Pada fase Organizing, bahan ajar memuat perintah kepada mahasiswa untuk mencari konsep yang berkenaan dengan relasi rekurensi dari berbagai sumber. Pada bagian Reflecting, bahan ajar memberikan kesempatan kepada mahasiswa untuk menuliskan konsep menurut 


\section{Revisi Bahan Ajar}

Sisi paling lemah hasil dari uji temuannya dari berbagai sumber. Pada bagian Extending, bahan ajar menyediakan kesempatan kepada mahasiswa untuk menyelesaikan tugas-tugas terkait dengan relasi rekurensi. Di bagian terakhir, bahan ajar memuat penilaian akhir bab relasi rekurensi.

Bahan ajar yang dikembangkan telah melalui uji validasi dan uji efektivitas. Hasil uji validasi menunjukkan bahwa bahan ajar valid dan efektif. Meskipun demikian, bahan ajar perlu direvisi berdasarkan saran dari validator maupun subjek.

Tabel 1. Revisi Terkait Ditemukannya Unsur Ambiguitas

\begin{tabular}{|c|c|c|}
\hline No & Sebelum Revisi & Setelah Revisi \\
\hline 1 & Menggunakan istilah "relasi rekursif" & Menggunakan istilah "relasi rekurensi" \\
\hline 2 & $\begin{array}{l}\text { Nama Kolom dalam Tabel } 2 \\
\text { - "Pasangan yang dapat melahirkan" } \\
\text { - "Pasangan muda" }\end{array}$ & $\begin{array}{l}\text { Nama Kolom dalam Tabel } 2 \\
\text { - "Pasangan yang dapat melahirkan } \\
\text { (berusia } \geq 2 \text { tahun)" } \\
\text { - "Pasangan muda (berusia }<2 \\
\text { tahun)" }\end{array}$ \\
\hline 3 & $\begin{array}{l}\text { Soal No. } 4 \text { halaman } 5 \\
\text { Peneliti perikanan mengasumsikan } \\
\text { bahwa banyaknya ikan haruan yang } \\
\text { tertangkap pada suatu tahun di suatu } \\
\text { kawasan rawa adalah rata-rata dari } \\
\text { banyaknya ikan yang tertangkap dua } \\
\text { tahun sebelumnya. Berdasarkan asumsi } \\
\text { tersebut: }\end{array}$ & $\begin{array}{l}\text { Soal No. } 4 \text { halaman } 5 \\
\text { Peneliti perikanan mengasumsikan } \\
\text { bahwa banyaknya ikan haruan yang } \\
\text { tertangkap pada suatu tahun di suatu } \\
\text { kawasan rawa adalah rata-rata dari } \\
\text { banyaknya ikan yang tertangkap dua } \\
\text { tahun terakhir. Berdasarkan asumsi } \\
\text { tersebut: }\end{array}$ \\
\hline
\end{tabular}

Selain unsur ambiguitas, peneliti dikembangkan. Perbaikan terkait kelengkapan memperhatikan tanggapan negatif dan saran dari subjek dalam hal unsur-unsur kelengkapan dalam bahan ajar yang

Tabel 2. Revisi Terkait Kelengkapan Unsur-Unsur Bahan Ajar

\begin{tabular}{cll}
\hline No. & \multicolumn{1}{c}{ Tanggapan Subjek } & \multicolumn{1}{c}{ Revisi Bahan Ajar } \\
\hline $\mathbf{1}$ & $\begin{array}{l}\text { kurangnya tautan sumber materi yang } \\
\text { bisa diakses }\end{array}$ & $\begin{array}{l}\text { Diberikan saran berupa kata kunci untuk } \\
\text { browsing materi melalui browser }\end{array}$ \\
\hline $\mathbf{2}$ & $\begin{array}{l}\text { kurangnya variasi tugas-tugas yang } \\
\text { diberikan }\end{array}$ & $\begin{array}{l}\text { Selain tugas yang diberikan di bahan ajar, } \\
\text { diberikan fitur pemberian tugas terstruktur } \\
\text { yang dipadukan dengan bahan ajar lain }\end{array}$ \\
\hline $\mathbf{3}$ & $\begin{array}{l}\text { Perlu ada bagian dari bahan ajar yang } \\
\text { dipadukan dengan video }\end{array}$ & $\begin{array}{l}\text { Diberikan saran berupa kata kunci untuk } \\
\text { browsing materi melalui Youtube atau kanal } \\
\text { video lain }\end{array}$ \\
\hline
\end{tabular}


Tanggapan "Sedikitnya ringkasan materi maupun contoh soal" tidak ditindaklanjuti karena bahan ajar dirancang secara praktis dan digunakan untuk membangun kemandirian mahasiswa dan memberikan petunjuk berupa kata-kata kunci di bahan ajar.
Fitur Penunjang Peningkatan Kemampuan Berpikir Tingkat Tinggi

Kemampuan berpikir tingkat tinggi dilihat dari ranah kognitif analisis, evaluasi, dan mencipta. Bahan ajar yang dikembangkan memperhatikan ketiga ranah kognitif tersebut. Ranah kognitif analisis, evaluasi, dan mencipta tersaji pada Tabel 3.

Tabel 3. Fitur Penunjang Meningkatkan Kemampuan Berpikir Tingkat Tinggi Mahasiswa

\begin{tabular}{|c|c|c|}
\hline No & $\begin{array}{l}\text { Ranah } \\
\text { Kognitif }\end{array}$ & Unsur di Bahan Ajar \\
\hline 1 & Analisis & $\begin{array}{l}\text { - Mahasiswa menganalisis kasus berupa masalah berkonteks lahan basah } \\
\text { terkait relasi rekurensi } \\
\text { - Mahasiswa mencari beberapa sumber definisi relasi rekurensi dan } \\
\text { prosedur pemecahan masalahnya sebelum menuliskannya menurut } \\
\text { bahasanya sendiri } \\
\text { - Mahasiswa menentukan perbedaan-perbedaan dari beberapa sumber } \\
\text { yang telah didapat }\end{array}$ \\
\hline 2 & Evaluasi & $\begin{array}{l}\text { - Mahasiswa menanggapi hasil diskusi kelompok lain maupun hasil } \\
\text { pekerjaan individu kawannya yang diunggah secara daring }\end{array}$ \\
\hline 3 & Mencipta & $\begin{array}{l}\text { - Mahasiswa menuliskan definisi relasi rekurensi dan prosedur pemecahan } \\
\text { masalahnya menurut bahasanya sendiri } \\
\text { - Mahasiswa membuat contoh-non contoh relasi rekurensi dan relasi } \\
\text { rekurensi homogen dengan koefisien konstan }\end{array}$ \\
\hline
\end{tabular}

\section{Keunikan dan Kelebihan Bahan Ajar}

Bahan ajar yang dikembangkan memperhatikan kearifan lokal Kalimantan Selatan sebagai kawasan dengan lingkungan lahan basah. Keunikan lain dari bahan ajar yaitu disajikan dengan sintaks pembelajaran model CORE (Connecting, Organizing, Reflecting, dan Extending). Selain itu, bahan ajar yang dikembangkan memuat konten dan instruksi tugas yang dapat merangsang siswa untuk meningkatkan kemampuannya dalam berpikir tingkat tinggi (menganalisis/ menyintesis, mengevaluasi, dan mencipta).
Subjek sebagai pengguna telah memberikan tanggapan terkait penggunaan bahan ajar yang dikembangkan. Kelebihankelebihan bahan ajar yang didapat dari tanggapan subjek.

Materi yang disajikan membuat mahasiswa aktif mencari tambahan materi dari sumber lain sehingga tidak pasif. Hal ini sesuai dengan pernyataan bahwa blended learning dapat memberikan kesempatan untuk belajar sesuai dengan gayanya (Wardani, Toenlioe, \& Wedi, 2018) dan secara bebas dapat mengeksplorasi sumber belajarnya (Widiara, 
2018) sehingga lebih menikmati dalam belajarnya (Rifa'i \& Sugiman, 2018). Selain itu, pembelajaran blended memberikan kemudahan bagi mahasiswa untuk dapat belajar di berbagai tempat sesuai dengan pernyataan (Borba et al., 2016) dan (Tseng, Kano, \& Hsu, 2014).

Mahasiswa lebih mudah apabila pembelajaran menggunakan model blended dan termotivasi untuk belajar. Hal ini sesuai dengan hasil penelitian yang dilakukan oleh (Bibi \& Jati, 2015; Diasa \& Diniz, 2012; Lin, Tseng, \& Chiang, 2017; Oweis, 2018; Syarif, 2012) bahwa blended learning dapat meningkatkan motivasi belajar.

Menuliskan konsep dengan bahasa sendiri membuat mahasiswa menjadi lebih mudah memahami materi sehingga dapat meningkatkan hasil belajar sesuai dengan pernyataan (Awodeyi, Akpan, \& Udo, 2014; Fazal \& Bryant, 2019; Oweis, 2018).

\section{Simpulan dan Saran}

\section{Simpulan}

Bahan ajar dikembangkan menurut prosedur pengembangan bahan ajar 4D (Define, Design, Develop, dan Disseminate). Pengembangan hanya difokuskan pada tahap Define, Design, dan Develop. Pada tahap develop, ahli yang dilibatkan sebagai validator sebanyak 2 orang pada sesi penilaian ahli. Hasil validasi bahan ajar adalah $\mathrm{Va}=3,38$ dan berskor lebih dari atau sama dengan 2 pada setiap aspek untuk masing-masing validator, sehingga bahan ajar dinyatakan valid. Setelah bahan ajar divalidasi, bahan ajar diuji keefektifannya dengan melibatkan 42 mahasiswa sebagai subjek pada sesi Uji Pengembangan (Developmental Testing). Hasil uji keefektifannya yaitu $\mathrm{Ka}=3,30$ dan berskor lebih dari atau sama dengan 2 pada setiap aspek di masing-masing subjek uji. Oleh karena itu, bahan ajar dinyatakan efektif.

\section{Saran}

Peneliti memberikan saran berdasarkan hasil penelitian yang dilakukan. Adapun saransaran tersebut yaitu:

1. Perlu diefektifkannya pemberianfeedback dari tugas-tugas yang sudah dikerjakan mahasiswa secara daring pada kelas tatap muka berikutnya atau via video/diskusi daring terkait tugas yang telah disubmit.

2. Perlu adanya demonstrasi/tutorial proses pengunggahan tugas via daring apabila pembelajaran blended learning pertama kali diterapkan di kelas.

\section{Daftar Pustaka}

Anisah, \& Lastuti, S. (2018). Pengembangan Bahan Ajar berbasis HOTS untuk Meningkatkan Kemampuan Pemecahan Masalah Matematis Mahasiswa. Kreano, 9(2), 191-197.

As'ari, A. R., Ali, M., Basri, H., Kurniati, D., \& Maharani, S. (2019). Mengembangkan HOTS (High Order Thinking Skills) melalui Matematika. Malang: Universitas Negeri Malang.

Awodeyi, A. F., Akpan, E. T., \& Udo, I. J. (2014). Enhancing Teaching and Learning of Mathematics: Adoption of Blended Learning Pedagogy in University of Uyo. International Journal of Science and Research (IJSR), 3(11), 40-45.

Bibi, S., \& Jati, H. (2015). Efektivitas Model Blended Learning Terhadap Motivasi dan Tingkat Pemahaman Mahasiswa Mata Kuliah Algoritma dan Pemrograman. 
Jurnal Pendidikan Vokasi, 5(1), 74-87.

Borba, M. C., Askar, P., Engelbrecht, J., Gadanidis, G., Llinares, S., \& Aguilar, M. S. (2016). Blended Learning, E-Learning and Mobile Learning in Mathematics Education. ZDM Mathematics Education, 48, 589-610. https://doi.org/10.1007/s11858-0160798-4

Broke, E. (2017). Four Keys to Success Using Blended Learning Implementation Models. Retrieved October 21, 2019, from www.lexialearning.com website: https://www.lexialearning.com/resources /white-papers/blended-learning-fourkeys

Bryan, A., \& Volchenkova, K. (2016). No Title. Bulletin of the South Ural State University, $\quad 8(2), \quad 24-30$. https://doi.org/https://doi.org/10.14529/p ed160204

Diasa, S. B., \& Diniz, J. A. (2012). Blended learning in Higher Education: different needs, different profiles. Proceedings of the 4th International Conference on Software Development for Enhancing Accessibility and Fighting Info-Exclusion (DSAI 2012), 438-446. https://doi.org/10.1016/j.procs.2012.10.0 50

Fazal, M., \& Bryant, M. (2019). Blended Learning in Middle School Math: The Question of Effectiveness. Journal of Online Learning Research, 5(1), 49-64.

Gazali, R. Y. (2016). Pembelajaran matematika yang bermakna. Math Didactic: Jurnal Pendidikan Matematika, 2(3), 181-190. https://doi.org/10.33654/math.v2i3.47

Hobri. (2010). Metodologi Penelitian Pengembangan. Jember: Pena Salsabila.
Lin, Y.-W., Tseng, C.-L., \& Chiang, P.-J. (2017). The Effect of Blended Learning in Mathematics Course. EURASIA Journal of Mathematics Science and Technology Education, 13(3), 741-770. https://doi.org/10.12973/eurasia.2017.00 $641 \mathrm{a}$

Maryati, \& Prahmana, R. C. I. (2018). Ethnomathematics: Exploring the Activities of Designing Kebaya Kartini. MaPan: Jurnal Matematika Dan Pembelajaran, 6(1), 11-19.

Mursalin, M., Nuraini, N. L. S., Purnomo, H., Damayanti, N. W., Kristanti, D., Rohim, A., \& Fonna, M. (2018). The development of algebra teaching materials to foster students' creative thinking skills in higher education. Journal of Physics: Conference Series, 1088(1), $1-6$. https://doi.org/10.1088/17426596/1088/1/012101

Musfiqi, S., \& Jailani. (2014). Pengembangan Bahan Ajar Matematika yang Berorientasi pada Karakter dan Higher Order Thinking Skill (HOTS). PYTHAGORAS: Jurnal Pendidikan Matematika, 9(1), 45-59.

Mutrofin, L., Nur, M., \& Yuanita, L. (2016). Developing Teaching Materials Using 5E Model of Instruction to Increase Students' higher Order Thinking Skills. JPPS (Jurnal Penelitian Pendidikan Sains), 5(2), 962-967. https://doi.org/http://dx.doi.org/10.26740 /jpps.v5n2.p962-967

Nur, F. (2017). Pengembangan Bahan Ajar Matematika Kelas VII SMP Berdasarkan Model Pembelajaran Kolb-Knisley Berbantuan Geogebra Sebagai Upaya Meningkatkan Higher-Order Thinking Skill dan Apresiasi Siswa Terhadap Matematika. MaPan : Jurnal Matematika Dan Pembelajaran, 5(1), 96 - 109. 
Oweis, T. I. (2018). Effects of Using a Blended Learning Method on Students' Achievement and Motivation to Learn English in Jordan: A Pilot Case Study. Education Research International, 2018, $1-7$.

https://doi.org/https://doi.org/10.1155/20 $18 / 7425924$

Rifa'i, A., \& Sugiman. (2018). Students' Perceptions of Mathematics Mobile Blended Learning Using Smartphone. J. Journal of Physics: Conference Series, 1097(2018),

$1-9$. https://doi.org/10.1088/17426596/1097/1/012153

Rohaeti, E. E. (2011). Transformasi Budaya Melalui Pembelajaran Matematika Bermakna di Sekolah. Jurnal Pengajaran MIPA, 16(1), 139-147.

Sari, M. (2016). Blended Learning, Model Pembelajaran Abad Ke-21 di Perguruan Tinggi. Ta'dib, Jurnal Fakultas Pendidikan Dan Pelatihan Guru, Universitas Batusangkar, 17(2), 126136.

Surya, E., \& Putri, F. A. (2017). Improving Mathematical Problem-Solving Ability and Self-Confidence of High School Students through Contextual Learning Model. Journal on Mathematics Education, 8(1), 85-94.

Syarif, I. (2012). Pengaruh Model Blended Learning Terhadap Motivasi dan Prestasi Belajar Siswa SMK. Jurnal Pendidikan Vokasi, 2(2), 234-249.

Tanujaya, B., Mumu, J., \& Margono, G. (2017). The Relationship between Higher Order Thinking Skills and Academic Performance of Student in Mathematics Instruction. International Education Studies, 10(11), 78-85.

Thiagarajan, S., Semmel, D. S., \& Semmel, M.
I. (1974). Instructional Development for Training Teacher of Exceptional Children. Bloomington Indiana: Indiana University.

Tseng, W.-S., Kano, T., \& Hsu, C.-H. (2014). Effect of Integrating Blended Teaching into Mathematics Learning for Junior High School Students. Journal of Computers and Applied Science Education, 1(2), 39-57.

Wardani, D. N., Toenlioe, A. J. E., \& Wedi, A. (2018). Daya Tarik Pembelajaran di Era 21 dengan Blended Learning. JKTP, 1(1), $13-18$.

Widiara, I. K. (2018). Blended Learning sebagai Alternatif Pembelajaran di Era Digital. PURWADITA, 2(2), 50-56. 